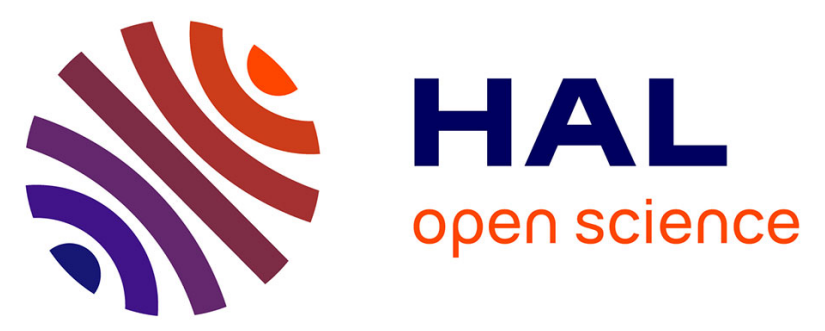

\title{
Seasonal demography of different black rat (Rattus rattus) populations under contrasting natural habitats in Guadeloupe (Lesser Antilles, Caribbean).
}

Jean Goedert, David Cochard, Arnaud Lenoble, Olivier Lorvelec, Benoît

Pisanu, Aurélien Royer

\section{To cite this version:}

Jean Goedert, David Cochard, Arnaud Lenoble, Olivier Lorvelec, Benoît Pisanu, et al.. Seasonal demography of different black rat (Rattus rattus) populations under contrasting natural habitats in Guadeloupe (Lesser Antilles, Caribbean).. Mammal Research, 2020, 65 (4), pp.793-804. 10.1007/s13364-020-00523-w . hal-02986612

\section{HAL Id: hal-02986612 \\ https://hal.science/hal-02986612}

Submitted on 30 Sep 2021

HAL is a multi-disciplinary open access archive for the deposit and dissemination of scientific research documents, whether they are published or not. The documents may come from teaching and research institutions in France or abroad, or from public or private research centers.
L'archive ouverte pluridisciplinaire HAL, est destinée au dépôt et à la diffusion de documents scientifiques de niveau recherche, publiés ou non, émanant des établissements d'enseignement et de recherche français ou étrangers, des laboratoires publics ou privés. 


\title{
Seasonal demography of different black rat (Rattus rattus) populations under contrasting natural habitats in Guadeloupe (Lesser Antilles, Caribbean)
}

Jean Goedert ${ }^{1 *}$, David Cochard ${ }^{1}$, Arnaud Lenoble ${ }^{1}$, Olivier Lorvelec ${ }^{2}$, Benoît Pisanu ${ }^{3,4}$, Aurélien Royer

\author{
${ }^{1}$ PACEA - UMR CNRS 5199, Université de Bordeaux, Pessac Cedex, France \\ ${ }^{2}$ ESE, Ecology and Ecosystems Health, INRAE, Agrocampus Ouest, 35042 Rennes, France \\ ${ }^{3}$ Centre d'Ecologie et des Sciences de la Conservation (CESCO UMR 7204), Sorbonne Universités, \\ MNHN, CNRS, UPMC, 43 rue Buffon, CP51, 75005 Paris, France \\ ${ }^{4}$ UMS 2006 Patrimoine Naturel, AFB, MNHN, CNRS, 36 rue Geoffroy Saint-Hilaire, 75005 Paris, \\ France
}

5 Biogéosciences, UMR 6282 CNRS, Université Bourgogne Franche-Comté, EPHE, 6 Boulevard Gabriel, 21000 Dijon, France

* Corresponding author: jean.goedert@protonmail.com

\begin{abstract}
The black rat (Rattus rattus) is one of the most widespread rodents on islands worldwide, introduced over the last five centuries. However, reliable information concerning how biotic or abiotic factors influence key parameters of black rat population biology in insular contexts is currently unavailable. Here we aim to document the relative abundance of rat populations and evaluate how the age structure and the bodymass of adult individual vary seasonally in different forest environments under contrasting climatic conditions. Rats were captured during wet and dry seasons in 2017-2018 at one or two sites in each of the four natural forested environments of Guadeloupe, all of which experience widely different annual rainfall (semi-deciduous dry forest, seasonal evergreen forest, mountain rainforest and Pterocarpus officinalis swamp forest). A total of 171 black rats were captured during a 1018 trap-night effort. Overall capture results confirm this species to thrive in all the natural forested environments we investigated. With the exception of the $P$. officinalis swamp forest, black rat populations reach higher relative abundances during the wet season due to juvenile and sub-adult recruitment at the end of the dry season. In contrast, in the $P$. officinalis swamp forest, breeding activity continues during both seasons and relative rat abundance appears to fluctuate less seasonally. The relative abundance of adult black rats is also higher in the seasonal semi-evergreen and rainforests that experience little or no water stress. These contexts therefore appear the most favourable for sustaining black rat populations, a pattern that is most likely connected to a combination of climatic and/or edaphic parameters that condition the year-round availability and abundance of food resources.
\end{abstract}

Key words: Black rat, Lesser Antilles, Ecology, Population, Precipitation

\section{Introduction}

Three commensal rodents arrived on European ships and subsequently colonized Guadeloupe: the house mouse (Mus musculus), the Norwegian rat or brown rat (Rattus norvegicus) and the black 
rat or roof rat (Rattus rattus), the latter most likely arriving as early as the seventeenth if not the sixteenth century (Pinchon 1967; Pregill et al. 1994; Lorvelec et al. 2007). The black rat, also known as the ship rat or roof rat, is a medium-sized commensal rodent native to the Indian subcontinent that was introduced almost worldwide, including numerous islands, by European ships (Atkinson 1985; Pascal et al. 2006; Aplin et al. 2011). Today, $80 \%$ of the world's archipelagos host black rat populations in climates ranging from tropical to sub-polar (Shiels et al. 2014). This remarkably adaptable species can establish non-commensal populations in various environments, especially forests where it lives as a semi-arboreal species (Quéré and Le Louarn 2011). The black rat is a highly opportunistic forager, which feeds primarily on fruits, seeds, arthropods, as well as numerous invertebrates and vertebrates (Shiels et al. 2014). Black rats reproduce multiple times each year, with a relatively short gestation period (between 20 and 29 days; Ewer 1971; Quéré and Le Louarn 2011) and a high number of young per litter (up to ten; Quéré and Le Louarn 2011). These characteristics highlight the remarkable adaptability of black rats that allow them to successfully inhabit a broad range of environments.

Although previous research has primarily focused on its social behaviour in captive colonies (Barnett 1958; Ewer 1971) and biology in commensal environments, particularly its role as a vector of diseases (e.g. Meerburg et al. 2009; Himsworth et al. 2014), in crop destruction (e.g. Pimentel et al. 2000, 2001; Singleton 2003) or as invasive species (e.g. Borroto-Páez 2009; Nowak and Walker 1999), relatively little has been reported on non-commensal populations in natural habitats (although see Harper and Bunbury 2015). Human dominated environments are less prone to food resource fluctuations than are natural ones, where the availability of food can vary substantially according to climatic conditions and seasonality. This explains why black rats in urban environments have a more rapid growth rate, reach sexual maturity quicker and are able to reproduce year-round compared with populations in natural environments (Feng and Himsworth 2014). In these latter contexts, the climate has been shown to be an important driver of rodent population dynamics (e.g. Ernest et al. 2000; Russell and Ruffino 2012). More specifically, several studies have highlighted the impact of rain fall on vegetation and food resources indirectly regulate black rat biology on tropical islands (e.g. Tamarin and Malecha 1971; Clark 1980; Harper and Bunbury 2015).

These studies have, however, mainly focused on Indian and Pacific island contexts, with little data available for the Caribbean. In fact, information concerning the biology of black rat populations in natural environments of the Caribbean derives primarily from research conducted in the early 1980s at two sites on Guadeloupe (Delattre and Le Louarn 1980, 1981).

Here we investigate the influence of rainfall regime and differing forested habitats on the demographic patterns of this invasive rodent on Guadeloupe during the wet and dry seasons based on data collected from trapped black rats. We hypothesize that forested habitats with marked hydric seasonality should support more variable black rat populations whose size varies seasonally compared with the climatically more stable forested habitats.

\section{Material and methods}

\section{Studied sites}

Guadeloupe is an island in the Lesser Antilles, this archipelago forming one of the world's biodiversity hotspots (Myers et al. 2000). The main island, Guadeloupe, comprises two adjoining islands: the volcanic and mountainous Basse-Terre, to the west, and the carbonated (limestone) lowlying Grande-Terre, to the east (Fig. 1).

Prior to European colonisation, Guadeloupe was likely covered almost entirely by forest (Rollet et al. 2010), an important part of which has since been deforested, especially in densely populated low-lying areas (Lugo et al. 1981), including selectively harvested old-growth forests. Natural forests do still remain in Guadeloupe and vary according to soil conditions and climatic factors (for details, see Lasserre 1961; Rousteau et al. 1994; Sastre et al. 2007; Rollet et al. 2010). Today, five main forest 
formations are present on Guadeloupe (Rousteau et al. 1994 and Fig. 1). Rats were captured from 7 sites within these five formations during two capture sessions.

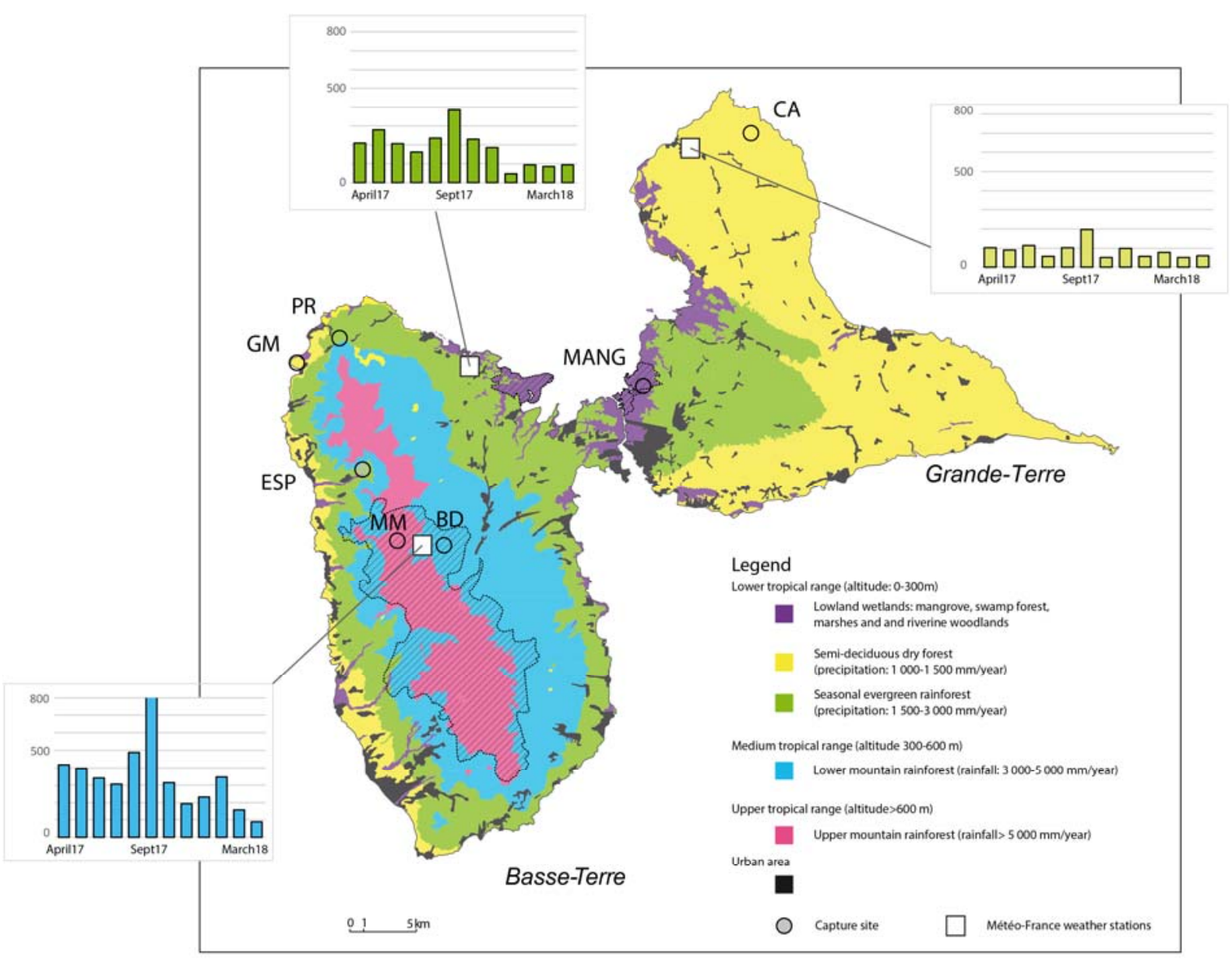

Figure 1. Vegetation maps of Guadeloupe (French West Indies) modified after Rousteau et al. (1994) and Sastre et al. (2007) with the location of the capture sites. Graphs illustrating monthly rainfall from April 2017 to March 2018 recorded at three Météo-France weather stations in different environmental settings. CA, Barre de Cadoue; MANG, Maison de la mangrove; PR, Piton Sainte-Rose; GM, Gros Morne de Deshaies; ESP, Espérance; MM, Mamelles; BD, Bras David

1 Semi-deciduous dry forest (capture sites: Gros Morne de Deshaies Basse-Terre GPS WGS 84 coordinates $16.32^{\circ} \mathrm{N},-61.8^{\circ} \mathrm{O}$; alt: $200 \mathrm{~m}$ and Barre de Cadoue Grande-Terre $16.48^{\circ} \mathrm{N} ; 61.44^{\circ}$ $\mathrm{O}$; alt: $40 \mathrm{~m}$ ) on the western coast of Basse-Terre and in the east and north of Grande-Terre. These forests are found below $300 \mathrm{~m}$ (a.s.l.) on the western side of Basse-Terre and cover most of the lower (less than $250 \mathrm{~m}$ a.s.l.) island of Grande-Terre. These forests receive less than 1500-2000 $\mathrm{mm}$ of annual rainfall and are marked by seasonal climatic variations, with a dry season extending from January to April/May, and a wet season extending from August to December. Barre de Cadoue is in a more xeric environment with a mean annual precipitation of less than $1400 \mathrm{~mm}$.

2 Seasonal evergreen forest (capture sites: Espérance western Basse-Terre $16.23^{\circ} \mathrm{N} ; 61.74^{\circ} \mathrm{O}$; alt: $300 \mathrm{~m}$ and Piton Sainte-Rose northern Basse-Terre $16.33^{\circ} \mathrm{N},-61.76^{\circ} \mathrm{O}$; alt: $320 \mathrm{~m}$ ) comprises evergreens mixed with a limited number of deciduous species and develops above 
the semi-deciduous dry forest at altitudes between 300 and $400 \mathrm{~m}$ (a.s.l.) on the western side and $100 \mathrm{~m}$ on the eastern side of Basse-Terre, in addition to semi-deciduous wet formations of western Grande-Terre, all of which receive between 1500 and 2000 and $3000 \mathrm{~mm}$ of annual precipitation. This is significantly more than what is recorded for the dry semi-deciduous forest between the wet and dry seasons.

3 Mountainous and sub-mountainous rainforest (capture sites: Bras David $16.17^{\circ} \mathrm{N} ; 61.69^{\circ} \mathrm{O}$; alt: $250 \mathrm{~m}$ ) at mid-elevations of the central ridge of the mountainous massif that receives an annual rainfall in excess of $2500-3000 \mathrm{~mm}$, with no sizeable seasonal fluctuations impacting vegetation phenology. These forests are found between 300 and 400 and $800 \mathrm{~m}$ (a.s.l.) and between 100 and $600 \mathrm{~m}$ (a.s.l.) to the west and east of the mountainous massif of Basse-Terre.

4 Altimontane formations (capture sites: Col des Mamelles $16.18^{\circ} \mathrm{N} ; 61.73^{\circ} \mathrm{O}$; alt: $550 \mathrm{~m}$ ) group together low bushes and altimontane rainforests on the upper portions of the Basse-Terre mountain range. These zones receive more than $2500 \mathrm{~mm}$ of annual rainfall in the north of the island and more than $4500 \mathrm{~mm}$ in the south. These forests develop above the mountainous and sub-mountainous rainforest at altitudes between 1000 and $1100 \mathrm{~m}$ (a.s.l.).

5 Wetlands (capture sites: Maison de la Mangrove located on the plains between Basse-Terre and Grande-Terre $16.29^{\circ} \mathrm{N} ;-61.53^{\circ} \mathrm{O}$; alt: $7 \mathrm{~m}$ ) that include mangroves, swamp forest, swampy plains and valley bottoms. Located in the low-lying areas $(<10 \mathrm{~m}$ (a.s.l.)) of the plains between Basse-Terre and Grande-Terre, the swamp forest is the most extensive freshwater wetland forest and is largely dominated by Pterocarpus officinalis (Imbert et al. 2000). Moderate seasonal variations mean that $P$. officinalis flowers and fruits throughout the year (two extensive blooming periods generally occur from July to September and from November to January). The swamp forest is the most productive forest in terms of fine litterfall (Migeot and Imbert 2012), which sustains a rich and diversefauna (Feagin et al. 2013).

All capture sites were located one to several hundred meters away from all human activities (e.g. habitations, crops, picnic areas) in order to best reflect the diversity of natural environmental conditions on Guadeloupe. During the second capture session in March 2018 (see below), several traps were set in agricultural areas close to the selected sites: two large fields dedicated to the large-scale production of sugarcane near Piton Sainte-Rose and Barre de Cadoue and a smaller sugarcane farm next to a Creole garden, near Espérance. For Barre de Cadoue, a supplementary test was carried out not far from "La Porte d'Enfer", at the edges of a marshy area.

\section{Capture session and climatic conditions}

Two capture sessions were conducted in order to record potential seasonal changes in black rat population biology and dynamic. The first one was carried out during the first 2 weeks of October $2017(04 / 10-13 / 10)$, which corresponds to near the end of the wet season. The second was carried out 5 months later during the middle of the dry season in March 2018 (14/03-27/03). The cyclone season in Guadeloupe usually falls just before the beginning of the dry season that spans from June to November. In 2017, the region experienced significant cyclone activity, with the annual average rainfall exceeding the norm (see Fig. 1). Records from Météo-France weather stations in Guadeloupe indicates that rainfall from November 2017 to January 2018 was slightly lower than expected and was accompanied by slightly warmer conditions compared with normal temperatures for the season (from+ 0.1 to $+0.4{ }^{\circ} \mathrm{C}$, Fig. 1). 


\section{Capture protocol}

Sixty rocker rat traps (Manufrance ${ }^{\mathrm{TM}}$; wire mesh; $26 \times 10 \times 10 \mathrm{~cm}$ ) were set along 1 to 3 parallel rows depending on the characteristics of each site (accessibility, slope). Traps were placed every $15 \mathrm{~m}$ along rows separated by $20 \mathrm{~m}$. GPS data was recorded for each trap. During each capture session, traps were set in the same locations according to the same configuration.

Traps were initially set at the end of afternoon and baited with a mixture of organic oats, peanut butter and sardine oil. Each trap was visited the next morning and recorded either as open (with or without bait) or sprung (rat, mongoose (Urva auropunctata), hermit crab (Coenobita clypeatus) or empty with or without bait). Rats were systematically killed immediately after being removed from the trap, with the traps subsequently rebaited and reset the same morning. Depending on the site and session of capture, the trap-night effort varied from one to two nights, except for Gros Morne de Deshaies and Barre de Cadoue during the second session, when traps were set for 3 and 5 nights, respectively (SI 1). In the latter case, baits were resupplied every two nights.

\section{Biological data}

The length (nose to anus and anus to tip of tail) and weight (total and eviscerated) were recorded for each captured rat, except for five who escaped. Although it has no taxonomic value, morphological information was also recorded (rattus, alexandrinus or frugivorous) to evaluate potential correlations between pelage colouration and the environment. All individuals were sexed, and the length of the testicles and number of placental scars or the number of embryos were recorded in order to determine the reproductive maturity for male and female specimens, respectively.

Both eyes were removed to determine the relative age of the cohort within each population (Lord 1959; Augusteyn 2008, 2014). Eye lenses were recovered through dissection, then fixed in formalin (12\%) for at least 2 months and subsequently dried at $80^{\circ} \mathrm{C}$ for $24 \mathrm{~h}$. Eppendorf vials were hermetically sealed in an oven following desiccation to avoid the lenses rehydrating prior to be weighed. Both lenses were weighed with a precision of 10-5 $\mathrm{g}$ and their mean weight calculated.

The skeleton of each individual was cleaned and inventoried with a specimen number as part of the comparative anatomy collection of the PACEA laboratory (UMR-5199 of the CNRS) at the University of Bordeaux.

\section{$\underline{\text { Trap success index }}$}

To describe the relative rat abundance between site and season of capture, we used the trap success index described by Nelson and Clark (1973); the total number of captured black rats was divided by the total trap-night effort (trap-night effort = number of traps set $\times$ number of night), multiplied by 100 and corrected by half of traps, which became ineffective in the total trapping effort (i.e. sprung for any reason, including rat capture) (Himsworth et al. 2014).

A confidence interval (I) for a $p$ value of $0.95 \%$ was calculated for each trap success index as:

$$
I=1,96 \sqrt{\frac{(p * 1-p)}{n}} * 100
$$

where $\mathrm{p}$ is the trap success index value divided by 100 and $\mathrm{n}$ is the total trap-night effort. 
All analyses were performed using simple or mixed modelling methods (Zuur et al. 2009) run in a Bayesian framework (Zuur et al. 2013) using the "brms" package (Bürkner 2017, 2018) for the R software version 3.5.3 (R Core Team 2019; see Online resource 2). Apart from the analysis of agerelated variation in corrected trapping rates by habitat and season that had too few replicated observations within sites, all models included a site random intercept to overcome heterogeneity in sample variance within trapping sites that may have biased coefficient estimations when comparing habitat or the influence of season across sites.

To define cohorts and separate juvenile, sub-adult and adult, we compared the reproductive state of each individual with their mean eye lens weight. Females with placental scars and/or embryos were considered sexually mature and coded as 1 , while females without any evidence of reproduction were coded as 0 . Males with testicular lengths greater than or equal to $2 \mathrm{~cm}$ were considered sexually mature and were coded as 1 , while those with lengths less than $2 \mathrm{~cm}$ long were coded to 0 . A generalized linear mixed model (GLMM) was generated for both female and male populations and adjusted with a binomial error (using a logit link function) adapted to presence/absence data.

A linear mixed model was used to test the significance of variations in adult rat mass (eviscerated weight) and to investigate the impact of habitat and season on this parameter and their interaction. The adjusted repeatability (Nakagawa and Schielzeth 2010) of the model was calculated to quantify the consistency in eviscerated body mass variation within sites when compared between habitats or season across sites.

A generalized linear mixed model adjusted with a betabinomial error (with a logit link function) adapted for modelling proportions based on a varying trial effort was employed to fit trapping rates corrected for sprung traps separating adult and juvenile plus sub-adult individuals according to habitat and season. No a priori probability was integrated in the statistical analyses. Gaussian priors were used to estimate the posterior distribution of model coefficients for the fixed part, and a half-Cauchy test $(0,25)$ was used for the random intercept estimates (Zuur et al. 2013). Three chains were run for 20,000 iterations after a burn-in of 10,000 iterations and a thinning rate of 10, yielding a 3000 posterior sample of estimated coefficients. Model convergence was graphically and numerically checked for all analyses (Rhat < 1.001; Online resource 2). For the binomial and beta-binomial GLMM, the dispersion parameter was checked to be close to 1.00 , ensuring an absence of heterogeneity in residual variance distribution, as well as for simple linear models that were graphically checked for homogeneity using Pearson residuals to fitted values relationship (Zuur et al. 2009, 2013). Detailed raw data used for statistical analyses along with step-by-step $\mathrm{R}$ codes are provided as online resources (Online resource 2).

\section{Results}

\section{Capture data}

The black rat was the only rodent species trapped during this study. Non-target species (mongoose and hermit crabs) also triggered traps in some instances, notably in the dry semi-deciduous forest sites. A total of 172 rats were captured during a 1018 trap-night effort. A 327 trap-night effort during the wet season (October 2017) resulted in the capture of 102 black rats, while a 691 trap-night effort during the dry season (March 2018) captured 69 black rats. SI 1 summarizes capture numbers along with the trap-night effort for each capture site and season as well as the relative age of individuals. Black rats were caught in the four natural environments; none was captured in a large industrial sugarcane field (trap-night effort $=80$ ), whereas seven rats were caught in the sugarcane field forming part of the creole garden (trap-night effort $=20$ ). Individuals from the semi-deciduous dry forests were mainly represented by the frugivorous morph; those from swamp forest were almost 
all alexandrinus, whereas those from the mountain rainforest tend to be mainly represented by the rattus morph.

The calculated trap success indices vary from 1.8\% for Barre de Cadoue during the dry season to $73.2 \%$ for Bras David during the wet season (Fig. 2). Except for the swamp forest, the trap success index is consistently higher for the wet season than during the dry season, suggesting a greater population density for the former. Only Gros Morne de Deshaies and Maison de la Mangrove sites show trap success indices lower than $40 \%$ during the wet season. During the dry season, trap success indices are below $40 \%$, especially for the semi-deciduous dry forest $(<7 \%)$, although the capture effort is greater for these two localities; seasonal evergreen forest sites show values ranging between 12 and $20 \%$, while mountain rainforest sites show trap success index closer to $30 \%$.

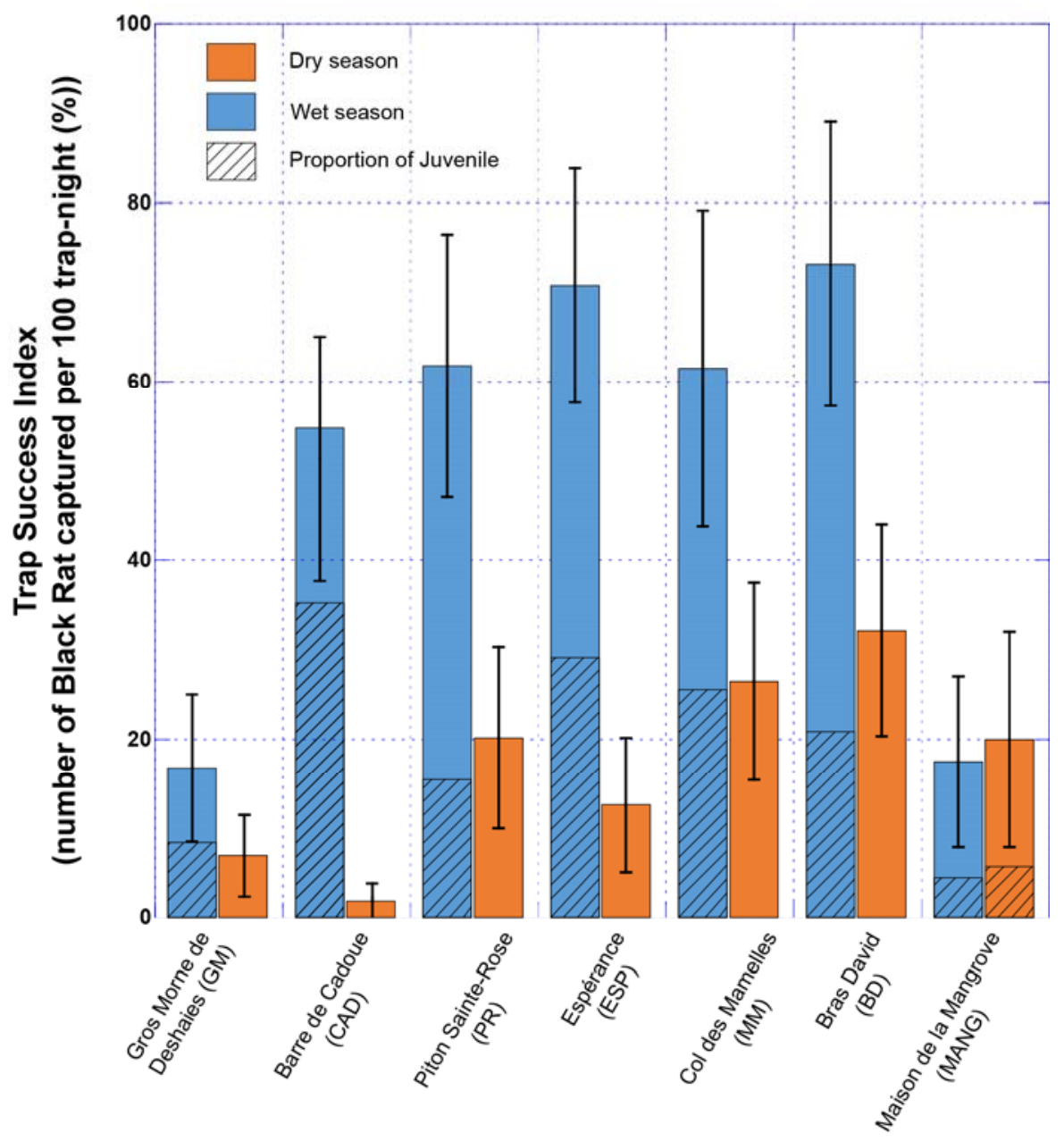

Figure 2. Trap success index by site and season with associated confidence intervals and proportions of captured juveniles. Trap success indices are corrected by half of the traps that were ineffective in the total trapping effort (i.e. sprung for any cause, including rat capture) (Himsworth et al. 2014)

\section{$\underline{\text { Relative age of black rats }}$}

Complete biological information was recorded for 166 individuals. Figure 3 presents growth models for male and female rats based on eye lens weights. In both cases, significant relationships exist between reproductive maturity indices and eye lens weight (Online resource 3 ). Based on these two models, we graphically defined the sub-adult class as specimens with mean eye lens weights of between 20 and $30 \mathrm{mg}$ (Fig. 3), while those with mean eye lens weight less than $20 \mathrm{mg}$ or greater than $30 \mathrm{mg}$ were attributed, respectively, to juvenile or adult age classes. 


\section{Variations in adult body weight}

Eviscerated body weight of adult black rats does not differ between sexes (Online resource 3 ) and ranges between $80 \mathrm{~g}$ and $173 \mathrm{~g}$ (mean $\pm 1 \mathrm{SE}: \mathrm{n}=57,118 \pm 3 \mathrm{~g}$ ). Although eviscerated body weight of adults captured in the semi-deciduousdry forest tends to be lower than individuals from the other sites (supplementary material), no significant variation is evident according to habitat or season (Online resource 3). Eviscerated body weight was consistent between sites, with the site random intercept comprising on average $19.6 \%$ of the total variance estimated by the linear mixed model (Online resource 3, cf. Nakagawa and Schielzeth 2010).

a) Females

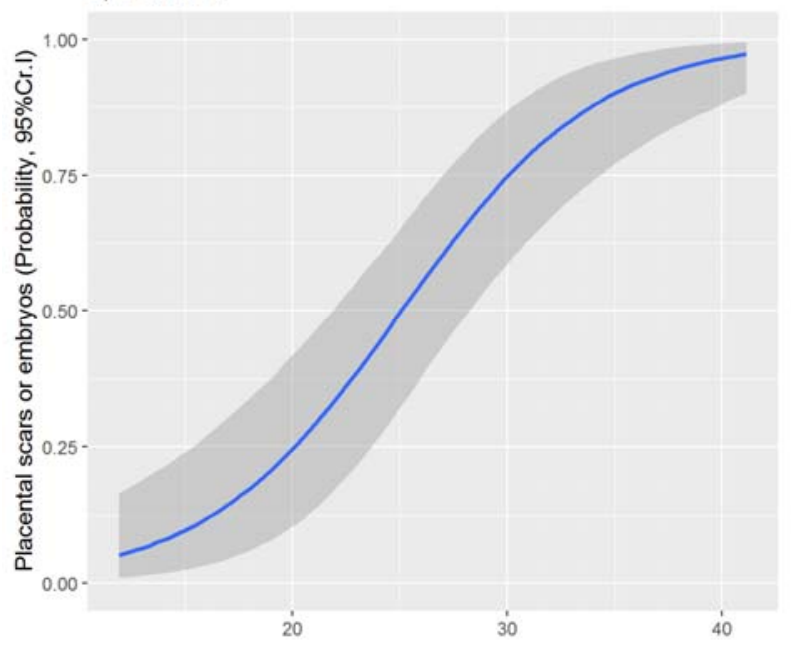

b) Males

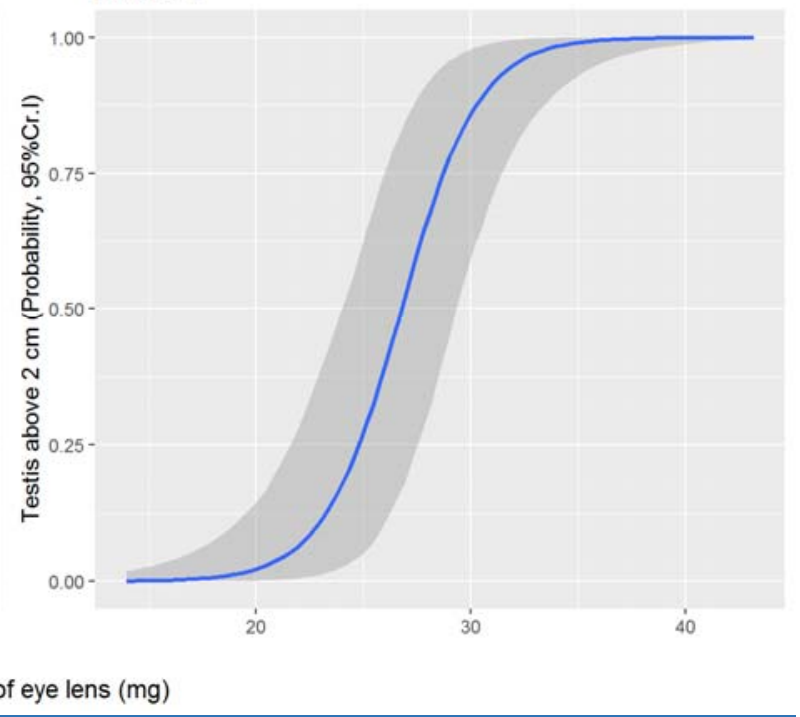

Figure 3. Logistic curve for captured male and female individuals calculated from eye lens weight (mg), testicle length (for males) and reproductive state (for females) based on placental scars

\section{Variations in age-related relative abundance according to environment}

Although variations in trap success indices are observable between seasons (Fig. 2), these variations should be assessed according to age class. During the wet season, corrected trapping rates for adult black rats ranged between 0.6 and $31.8 \%$, while during the dry season rates ranged between 0.3 and $11.9 \%$ (Online resource 1). While this difference between seasons is evident visually, the associated probability is almost significant but still falls within the credible interval (Online resource 3). However, trapping rates for adult black rats were significantly lower in the semi-deciduous dry forest compared with the mountain rainforest (Online resource 3; Fig. 4).

Including juveniles and sub-adults, hereafter referred to as young black rats, the corrected trapping rates were strikingly different, being null during the dry season and ranging between 7.1 and $42.9 \%$ during the wet season (Online resource 1; Fig. 4), except in the swamp forest, where young black rats were trapped in equal numbers independent of the season. 


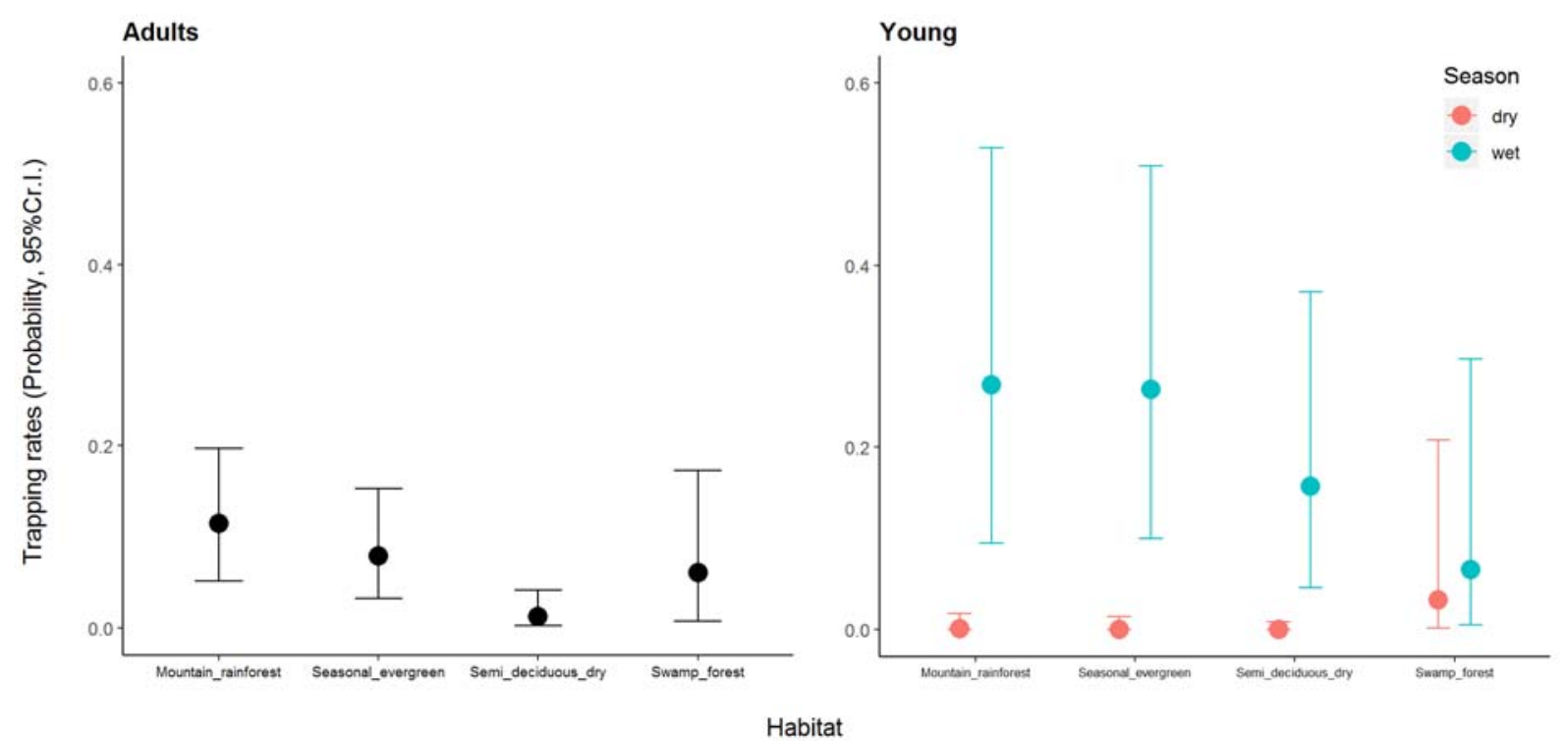

Figure 4. Variations in age-related corrected trapping rates for black rats (Rattus rattus) in Guadeloupe according to habitat and season

\section{Discussion}

Numerous mammals occupy environments with seasonal variations that condition food availability, the photoperiod, climatic parameters (i.e. temperature, humidity) and energetic demands, which in turn influence several biological traits, including reproductive development and population density or growth (e.g. Bronson 1989, 2009). In Guadeloupe, seasonal contrasts in rainfall between dry and wet seasons, combined with the effects of local topography, shape the distribution of vegetation on the island and consequently local rat population biology and dynamics. Our results are in agreement with previous research on black rats in the Lesser Antilles (Delattre and Le Louarn 1980, 1981) and show that the density and breeding activity of black rat populations on Guadeloupe are largely controlled by seasonal rainfall. Moreover, our data provides new insights concerning the impact of environmental conditions on both relative population abundance and structure.

\section{Population relative abundance}

The black rat is a commensal species that thrives alongside humans and in natural environments throughout the world. Previous research (Pascal et al. 2004) described an uneven distribution of these species in Guadeloupe, with the black rat being less often associated with human activity than either the house mouse or Norwegian rat, both of which were found to be more abundant in urban and agricultural ecosystems, a pattern typical of tropical island contexts (e.g. Harper and Bunbury 2015). They also found that Norwegian rat was less abundant than black rat and virtually absent in natural environments where human pressure is low. Our capture data confirm this spatial heterogeneity in Guadeloupe; no Norwegian rats were captured despite an important trap-night effort of capture. This is consistent with the fact that black rats are the superior competitors in forest habitats (Harper 2006). It is also worth noting that no black (or Norwegian) rats were captured in the two industrial sugarcane fields (Online resource 1). This is consistent with a previous study (Pascal et al. 2004) that equally reported a low capture success in this kind of crop. Several hypotheses may explain the absence of black rats in these contexts: the use of rat poison, sugarcane varieties resistant to rat attacks or our trapping strategy. For instance, our traps were positioned at the edges of the sugarcane fields, an area which has been previously reported to support a lower density of rats (Lefebvre et al. 
1989). We did, however, capture several black rats in a small sugarcane field within traditional creole gardens surrounded by forest near the capture site of Espérance. Therefore, another explanation is that pure sugarcane plantations present less suitable habitats for black rats. The limited number of trees compared with forest contexts would therefore account for their relative abundance in sugarcane fields next to forests. Similarly, Norway rats are highly vulnerable to predation by mongoose in this habitat as there are no refuges for them, unlike commensal areas where they are abundant. Mice may be present in forests with black rats but are unlikely to be detected without first removing black rats (Harper and Cabrera 2010).

Previous work concerning the presence of the black rat in natural environments of Guadeloupe recorded it as occurring uniquely in deciduous dry and seasonal evergreen forests (Delattre and Le Louarn 1980). The wide distribution of rats in the natural and anthropized environments in Guadeloupe was confirmed by subsequent capture sessions (Lorvelec et al. 2001, 2004). Our data complements this analysis by further demonstrating the presence of the black rat in all the main types of forests on Guadeloupe, while also providing an estimate of its relative abundance for each forest context during both wet and dry seasons. Up until now, the only available trapping data for Guadeloupe was available in Pascal et al. (2004), who reported an uncorrected trap success index of $12.5 \%$ for a site located at the lower limits of the rainforest during the early dry season. This station is located along a forest track in a former logging area, and therefore, an environment that was likely to have been biologically depleted by the selective exploitation of tree species as well as soil erosion induced by deforestation. Nevertheless, this capture rate is comparable to what was recorded for the seasonal evergreen forest during the peak dry season. Our results for both seasons, which includes sites that better reflect the different forest environments on the island, provide a more reliable picture of the black rat abundance in the natural environments of Guadeloupe.

Furthermore, our data clearly demonstrate the success index to vary according to both season and environment, a pattern previously observed by Delattre and Le Louarn (1980) for seasonal forests (dry deciduous and seasonal evergreen). Only Maison de la Mangrove and Gros Morne de Deshaies do not follow this trend; both sites are, in fact, characterized by lower and less variable trap success index for both seasons.

More generally, our trap success indices appear to be relatively similar to other tropical islands, such as Seychelles, and considerably higher than those reported from the temperate environment, such New Zealand (e.g. Harper and Bunbury 2015). For instance, Innes et al. (2001) reported trap success indices for black rats ranging from 0 to $9.2 \%$ for the different environments of New Zealand, while Efford et al. (2006) found a similar trap success index when estimating the density of black rat populations in the Orongorongo Valley, New Zealand, over a 15-year period. In contrast, Hill et al. (2003) reported much more variable trap success values from eight islands of the Seychelles archipelago, ranging from 17.5 to $99.5 \%$ and from 3.8 to $63.2 \%$ for the wet and dry seasons, respectively. The trap success values we calculated for the different Guadeloupe environments vary between 1.8 and $73.2 \%$ and are much more comparable to those obtained from Seychelles than those from New Zealand. In fact, except for the two low trap success values obtained for the semi-deciduous tropical dry forest, all others are greater than 10\% (Fig. 2).

\section{Population dynamics and seasonal cycle}

Although the black rat can breed year-round (Gomez 1960; Innes et al. 2001), population densities have been observed to fluctuate seasonally in many environments (e.g. Gomez 1960; Tamarin and Malecha 1971; Innes 1979; Clark 1980; Innes et al. 2001; Hill et al. 2003; Harper et al. 2005; Stapp and Polis 2003a; Efford et al. 2006; Russell and Ruffino 2012; Russell et al. 2011; Harper et al. 2014; Ringler et al. 2014; Harper et al. 2015; Harper and Rutherford 2016). This decline in breeding activity is generally interpreted as related to harsher climatic conditions and lower food availability in the environment (e.g. Clark 1980). Black rat population dynamics, however, appears to be no more stable on tropical islands, where seasonal climate conditions are neither too cold nor too 
dry compared with temperate islands such as those typical of New Zealand. On the contrary, black rat populations on tropical islands can highly fluctuate and reach higher densities than those typical of temperate islands. This is probably due to higher primary productivity and food availability that permit higher production, recruitment and survival of offspring (Harper and Bunbury 2015). Moreover, demographic patterns vary between populations inhabiting neighbouring islands (Hill et al. 2003; Russell et al. 2011) or even the same island, if it is sufficiently large enough to host different climatic conditions and environments (Delattre and Le Louarn 1980; Clark 1980; Harper et al. 2015). Nonetheless, in most cases, seasonal fluctuations in black rat populations are principally due to the recruitment of young individuals after the breeding period. On tropical islands, breeding patterns are mostly seasonal and controlled by precipitation (Tamarin and Malecha 1971, Clark 1980; Hill et al. 2003; Stapp and Polis 2003b; Russell et al. 2011; Russell and Ruffino 2012; Harper et al. 2014, 2015; Ringler et al. 2014). In these contexts, substantial seasonal and altitudinal variations in rainfall produce contrasting environments on the same island (Beard 1948). This is equally the case on Guadeloupe, where mean annual precipitation varies from less than $1500 \mathrm{~mm}$ in the semi-deciduous dry forest on the eastern coast of Grande-Terre Island to more than $5000 \mathrm{~mm}$ in the mountain rainforest of BasseTerre Island. Delattre and Le Louarn (1980) suggested that these contrasting annual precipitation rates controlled the breeding patterns of the rat population in the different Guadeloupe environments.

Our data clearly show the impact of seasonality on the relative abundance of captured young rats. During the dry season, no juvenile rats were caught, except in the swamp forest, while a higher number of juveniles were captured during the wet season, with proportions ranging from 25 to $70 \%$ according to the locality (Fig. 2). On average, the highest proportions of trapped rats come from the mountain and evergreen forest habitats and the lowest in the semi-deciduous dry forest and $P$. officinalis swamp forest. This pattern is in good agreement with data from Delattre and Le Louarn (1980), who showed that the highest density of black rats occurred during September-October, a period which also corresponds to the maximum number of juveniles in the population during the year (26\%).Moreover, in our study, few pregnant females with embryos were captured in all forest environments during the dry season. This observation, combined with the fact that no juveniles were caught during the dry season (except for the $P$. officinalis swamp forest), suggests that the onset of the reproductive cycle coincides with the arrival of the summer rains (Delattre and Le Louarn 1980), even in habitats with substantial annual rainfall.

These seasonal changes in both rat density and proportions of juveniles clearly separate the $P$. officinalis swamp forest from the other environmental contexts. Capture data from the swamp forest show that rats breed in October (wet season) as well as in March (dry season; one female had embryos). The low number of individuals and juveniles captured during both seasons in the swamp forest may therefore suggest that rats breed continuously in this specific environment. This contrasts with Delattre and Le Louarn's (1981) observations of a decrease in reproduction during the middle of the dry season (February to March) based on regular captures over a 2-year period. This apparently continuous breeding activity reflected in our data could thus be an artefact of a smaller number of capture sessions (only 2), suggesting some caution in their interpretation. Nevertheless, the different patterns in relative rat abundance and the proportion of juveniles observed during our study between the $P$. officinalis swamp forest and the other forested environments strongly suggest a more subtle, or at least less marked, seasonal effect. In addition, the interpretation of a continuous reproductive cycle in the $P$. officinalis swamp forest is supported by black rat behavior in comparable mangrove environments (Harper et al. 2015).

Delattre and Le Louarn (1981) proposed that the relative stability and lower density of black rat populations in the $P$. officinalis swamp forests are constrained by food availability in this particular environmental context. Our data are consistent with this interpretation when the higher trap success index and higher seasonal variations of young individuals trapped in low or no-water-stressed forests (seasonal evergreen and mountainous forests, respectively) in comparison to swamp forests are taken into account. Although limited, resources in this area are available throughout the year. In fact, the monodominant tree species $P$. officinalis produces two massive flowering blooms, from May to December, followed later by massive fruiting (Migeot and Imbert 2012). Furthermore, even if the 
Maison de la Mangrove is located in a freshwater environment, it is situated close to the canal of "Belle-Plaine", where aquatic fauna (fish and crustaceans) may assimilate marine-derived food resources from the nearby mangrove environment (François-Lubin 2005). The incorporation of marine resources in the diet of black rats inhabiting the $P$. officinalis swamp forest has been hinted at by the carbon isotope analysis of the carbonate component of tooth enamel (Goedert et al. in press). Greater availability of food resources throughout the year in swamp forest habitats therefore potentially underlies the more favourable conditions for black rat populations in these habitats compared with the semi-deciduous dry forest, a likelihood supported by the comparison of trap success rates between these two environments. These results are similar to those obtained in the Seychelles, where mangrove forests provide food sources for rat populations throughout the year and thus constitute much more favourable environments compared with surrounding dry forests (Harper et al. 2014, 2015), although stress due to limited freshwater availability can play a more important role in the latter.

It is also worth noting that data from Bras David and Col des Mamelles included no young individuals captured during the dry season and thus suggests a seasonal pattern in breeding activity. This result is in itself surprising, as these two sites are located in the mountain rainforest typified by no marked seasonal fluctuations in precipitation or local vegetation.

Consequently, no restrictions on food source availability should be expected in these contexts. Other factors, such as higher altitudes, humidity, wind exposure and nebulosity associated with temperature changes, solar input and reduced soil drainage, which are also known to produce less luxuriant forest conditions, lower growth rate and tree height, all likely contribute to seasonal reproductive patterns amongst black rats (e.g. Beard 1948; Weaver and Murphy 1990; Rousteau 1996; Sastre et al. 2007). Several population-specific characteristics also likely underlie such differences, as is evident by the relatively high consistency in site-specific variation in eviscerated bodymass, indicating that local or intrinsic factors influence rat body condition or growth status. With that said, better understanding the factors that control differences in rat body mass and their significance requires a larger dataset than the one devised for this study, including both more captured specimens and a higher number of capture sites. Notably, a larger dataset would facilitate testing the trend towards lower body weights observed for black rats living in the semi-deciduous dry forest, as well any possible correlation with less intense breeding activity reflecting an adaptive response developed by these populations to this particular environmental context in order to cope with harsher seasonal climatic conditions. Ultimately, such a study would provide insights into how black rats adapted their population biology to be highly successful across a variety of habitats on a single tropical island.

\section{Conclusion}

The black rat is a successful invasive species capable of reproducing in a wide variety of environments. Our results show its demography to be primarily impacted by seasonal climatic factors and habitat features. Rainfall regimes, which vary both seasonally and in intensity, condition the primary production and phenology of flowering and fruiting and consequently the entire food web. These constraints directly influence black rat populations, leading to the adoption of the distinct reproductive dynamics observed in our study. Despite this high degree of variability, our capture data not only demonstrates black rats to thrive in all the natural environment contexts of Guadeloupe but also highlights the remarkable adaptability of this introduced mammalian species. 


\section{Acknowledgements}

The authors would like to thank the Guadeloupe National Park agents who provided the rat traps used during the capture sessions. A special thanks go to Daniel Imbert (University of Antilles), who helped us identify the capture sites and lent us some equipment. The authors are also grateful to "Météo-France" for providing data concerning weather conditions in Guadeloupe. The authors would also like to thank Zoé Thalaud for her help in preparing the rat skeletal material and the acquisition of biological data.

\section{Author's contributions}

J.G., D.C., O.L., C.O., M.-T.C., A.R. and A. L. conceived the project. J.G. conducted stable isotopic analyses. C.O. and M.-T.C. conducted radiocarbon analyses. J.G., D.C., O.L., C.O., A.R. and A. L. wrote the manuscript.

\section{Funding information}

This study was conducted as a part of the CNRS ECSIT Project: "Écosystèmes insulaires tropicaux, réponse de la faune indigène terrestre de Guadeloupe à 6000 ans d'anthropisation du milieu », with financial support from the European PO-FEDER program (grant $n^{\circ}$ 2016-FED-503), the Guadeloupe Regional Council, and the DAC of Guadeloupe.

\section{Availability of data and material}

The authors declare that the data supporting the findings of this study are available within the manuscript and its supplementary information.

\section{Compliance with ethical standards}

\section{Conflict of interest}

The authors declare that they have no conflict of interest.

\section{Ethics approval}

Trapping operations were reported to the ONCFS regional office and authorizations were provided by the Guadeloupe National Park (permits PNG-2017-81 and PNG-2018-15). This study did not involve any endangered or protected species. None of the captured black rats were subjected to experiments involving extended stress or suffering. All specimens were killed following recommendations (regulation UE 2010/63) for the small mammals weighing less than $1 \mathrm{~kg}$ (Annex IV).

\section{References}

Aplin KP, Suzuki H, Chinen AA, Chesser RT, Ten Have J, Donnellan SC, Austin J, Frost A, Gonzalez JP, Herbreteau V, Catzefli $F(2011)$ Multiple geographic origins of commensalism and complex dispersal history of black rats. PLoS One 6(11): e26357 
Atkinson IA (1985) The spread of commensal species of Rattus to oceanic islands and their effects on island avifaunas. ICPB Tech Publ 3: 35-81

Augusteyn RC (2008) Growth of the lens: in vitro observations. Clin Exp Optom 91(3):226-239

Augusteyn RC (2014) Growth of the eye lens: I Weight accumulation in multiple species Molecular vision, 20, 410

Barnett SA (1958) An analysis of social behaviour in wild rats. In Proceedings of the Zoological Society of London Vol. 130 (No. 1, pp. 107-152). Oxford, UK: Blackwell Publishing Ltd

Beard JS (1948) The natural vegetation of the Windward and Leeward Island. Oxford Forestry Memoirs 21. Clarendon Press, Oxford

Borroto-Páez R (2009) Invasive mammals in Cuba: an overview. Biol Invasions 11: 2279-2290

Bronson FH (1989) Mammalian reproductive biology. University of Chicago Press

Bronson FH (2009) Climate change and seasonal reproduction in mammals. Philos T R Soc B 364(1534): $3331-3340$

Bürkner P (2017) brms: An R package for Bayesian multilevel models using Stan. J Stat Softw 80(1): 128

Bürkner P (2018) Advanced Bayesian multilevel modeling with the R package brms. R J 10(1): 395-411

Clark DB (1980) Population ecology of Rattus rattus across a desert montane forest gradient in the Galapagos Islands. Ecology 61(6): 1422-1433

Delattre P, Le Louarn H (1980) Cycle de reproduction du rat noir (Rattus rattus) et du surmulot (Rattus norvegicus) dans différents milieux de la Guadeloupe (Antilles françaises). Mammalia 44(2): 233244

Delattre P, Le Louarn H (1981) Dynamique des populations du rat noir, Rattus rattus, en mangrove lacustre. Mammalia 45(3): 275-288

Efford MG, Fitzgerald BM, Karl BJ, Berben PH (2006) Population dynamics of the ship rat Rattus rattus L. in the Orongorongo Valley, New Zealand. N Z J Zool 33(4): 273-297

Ernest SM, Brown JH, Parmenter RR (2000) Rodents, plants, and precipitation: spatial and temporal dynamics of consumers and resources. Oikos 88(3): 470-482

Ewer RF (1971) The biology and behaviour of a free-living population of black rats (Rattus rattus). Animal behaviour monographs

Feagin RA, Toledo-Rodriguez F, Colón-Rivera RJ, Smeins F, Lopez R (2013) Species composition and differences in diversity among the Pterocarpus officinalis forested wetland

Feng AY, Himsworth CG (2014) The secret life of the city rat: a review of the ecology of urban Norway and black rats (Rattus norvegicus and Rattus rattus). Urban Ecosyst 17(1): 149-162

François-Lubin V (2005) Les peuplements de poissons des canaux et des rivières de mangroves : le cas du canal Belle-Plaine:(Grand Cul-de-Sac Marin, Guadeloupe). Doctoral dissertation, AntillesGuyane University, Pointe-à-Pitre

Goedert J, Cochard D, Lorvelec O, Oberlin C, Cuzange M-T, Royer A, Lenoble A (in press) Isotopic ecology of the extinct Lesser Antillean rat Antillomys rayi. Quat Sci Rev

Gomez N (1960) Correlation of a population of roof rats in Venezuela with seasonal changes in habitat. Am Midl Nat 63: 177-193

Harper GA (2006) Habitat use by three rat species (Rattus spp.) on an island without other mammalian predators. N Z J Ecol 30(3): 321-333

Harper GA, Bunbury N (2015) Invasive rats on tropical islands: their population biology and impacts on native species. Glob Ecol Conserv 3: 607-627

Harper GA, Cabrera LF (2010) Response of mice (Mus musculus) to the removal of black rats (Rattus rattus) in arid forest on Santa Cruz Island, Galapagos. Biol Invasions 12: 1449-1452

Harper GA, Rutherford M (2016) Home range and population density of black rats (Rattus rattus) on a seabird island: a case for a marine subsidised effect? N Z J Ecol 40(2): 219-228

Harper GA, Dickinson KJ, Seddon PJ (2005) Habitat use by three rat species (Rattus spp.) on Stewart Island/Rakiura, New Zealand. N Z J Ecol:251-260

Harper G, Van Dinther M, Bunbury N (2014) Black rats in mangroves: successful and intractable. In Proceedings of the Vertebrate Pest Conference (Vol. 26, No. 26) 
Harper GA, van Dinther M, Russell JC, Bunbury N (2015) The response of black rats (Rattus rattus) to evergreen and seasonally arid habitats: informing eradication planning on a tropical island. Biol Conserv 185: 66-74

Hill MJ, Vel T, Shah NJ (2003) The morphology, distribution and conservation implications of introduced rats, Rattus spp. in the granitic Seychelles. Afr J Ecol 41(2): 179-186

Himsworth CG, Jardine CM, Parsons KL, Feng AY, Patrick DM (2014) The characteristics of wild rat (Rattus spp.) populations from an inner-city neighborhood with a focus on factors critical to the understanding of rat-associated zoonoses. PLoS One 9(3): e91654

Imbert D, Bonhême I, Saur E, Bouchon C (2000) Floristics and structure of the Pterocarpus officinalis swamp forest in Guadeloupe, Lesser Antilles. J Trop Ecol 16(1): 55-68

Innes J (1979) Diet and reproduction of ship rats in the northern Tararuas. N Z J Ecol 2(8)

Innes JG, King CM, Flux M, Kimberley MO (2001) Population biology of the ship rat and Norway rat in Pureora Forest Park, 1983-87. New Zealand Journal of Zoology 28(1): 57-78

Lasserre G (1961). La Guadeloupe, étude géographique. Union française d'impression, Bordeaux, 2 vol., $1135 \mathrm{p}$

Lefebvre LW, Engeman RM, Decker DG, Holler NR (1989) Relationship of roof rat population indices with damage to sugarcane. Wildl Soc Bull 17(1): 41-45

Lord RD (1959) The lens as an indicator of age in cottontail rabbits. J Wildl Manag 23(3): 358-360

Lorvelec O, Pascal M, Paris C (2001) Inventaire et statut des Mammifères des Antilles françaises (hors Chiroptères et Cétacés), pp. 1-21. Association pour l'Etude et la protection des Vertébrés et végétaux des petites Antilles (AEVA), Petit-Bourg, Guadeloupe

Lorvelec O, Delloue X, Pascal M, Mège S (2004) Impacts des mammifères allochtones sur quelques espèces autochtones de l'îlet Fajou (réserve naturelle du Grand cul-de-sac marin, Guadeloupe), établis à l'issue d'une tentative d'éradication. Rev d'Écol (La Terre et la Vie) 59(1/2) : 293-307

Lorvelec O, Pascal M, Delloue X, Chapuis J-L (2007) Les mammifères terrestres non volants des Antilles françaises et l'introduction récente d'un écureuil. Rev d'Écol (La Terre et la Vie) 62(4) : 295-314

Lugo AE, Schmidt R, Borwn S (1981) Tropical forests in the Caribbean. Ambio 10(6): 318-324

Meerburg BG, Singleton GR, Kijlstra A (2009) Rodent-borne diseases and their risks for public health. Crit Rev Microbiol 35(3): 221-270

Migeot J, Imbert D (2012) Phenology and production of litter in a Pterocarpus officinalis (Jacq.) swamp forest of Guadeloupe (Lesser Antilles). Aquat Bot 101: 18-27

Myers N, Mittermeier RA, Mittermeier CG, Da Fonseca GA, Kent J (2000) Biodiversity hotspots for conservation priorities. Nature 403(6772):853-858

Nakagawa S, Schielzeth H (2010) Repeatability for Gaussian and non-Gaussian data: a practical guide for biologists. Biol Rev 85: 935-956

Nelson L, Clark FW (1973) Correction for sprung traps in catch/effort calculations of trapping results. J Mammal 54(1):295-298

Nowak RM, Walker EP (1999) Walker's Mammals of the World (Vol. 1). JHU Press

Pascal M, Lorvelec O, Borel G, Rosine A (2004) Rodent community structures in agricultural and natural ecosystems of Guadeloupe and Martinique (French West Indies). Rev d'Écol (La Terre et la Vie) 59(1-2): 283-292

Pascal M, Lorvelec O, Vigne J-D (2006) Invasions Biologiques et Extinctions : 11000 Ans d'Histoire des Vertébrés en France. Editions Belin \& Quæ, Paris

Pimentel D, Lach L, Zuniga R, Morrison D (2000) Environmental and economic costs of nonindigenous species in the United States. Bioscience 50: 53-65

Pimentel D, McNair S, Janecka J, Wightman J, Simmonds C, O'connell C, Wong E, Russel L, Zern J, Aquino $\mathrm{T}$, Tsomondo $\mathrm{T}$ (2001) Economic and environmental threats of alien plant, animal, and microbe invasions. Agric Ecosyst Environ 84(1): 1-20

Pinchon R (1967) Quelques aspects de la Nature aux Antilles. Fort-de-France, Martinique

Pregill GK, Steadman DW, Watters DR (1994) Late Quaternary vertebrate faunas of the Lesser Antilles: historical components of Caribbean biogeography. Bull Carnegie Mus Nat Hist 37: 1-51 
Quéré JP, Le Louarn H (2011) Les rongeurs de France : Faunistique et biologie-3e édition revue et augmentée. Editions Quae

R Core Team (2019) R: A Language and Environment for Statistical Computing. R Foundation for Statistical Computing. https://www.r-project.org/. Accessed Mar 2020.

Ringler D, Russell J, Jaeger A, Pinet P, Bastien M, Le Corre M (2014) Invasive rat space use on tropical islands: implications for bait broadcast. Basic Appl Ecol 15(2):179-186

Rollet B, Fiard JP, Huc R (2010). Arbres des Petites Antilles. 2 vol. Office national des Forêts, Paris

Rousteau A (1996). Structures, flores, dynamiques : réponses des forêts pluviales des Petites Antilles aux milieux montagnards. Phytogéographie tropicale : réalités et perspectives. ORSTOM editions, Paris, 308-321

Rousteau A, Portecop J, Rollet B (1994) Carte écologique de la Guadeloupe. ONF, UAG, PNG, CGG, Jarry Russell JC, Ruffino $L$ (2012) The influence of spatio-temporal resource fluctuations on insular rat population dynamics. Proc R Soc B Biol Sci 279(1729): 767-774

Russell JC, Gleeson DM, Le Corre M (2011) The origin of Rattus rattus on the îles Éparses, Western Indian Ocean. J Biogeogr 38(9): 1834-1836

Sastre C, Breuil A, Bernard JF, Feldmann P, Fournet J (2007). Plantes, milieux et paysages des Antilles françaises : écologie, biologie, identification, protection et usages. Biotope

Shiels AB, Pitt WC, Sugihara RT, Witmer GW (2014) Biology and impacts of Pacific island invasive species. 11. Rattus rattus, the black rat (Rodentia: Muridae). Pac Sci 68(2): 145-184

Singleton $G$ (2003) Impacts of rodents on rice production in Asia. IRRI, Los Baños

Stapp P, Polis GA (2003a) Marine resources subsidize insular rodent populations in the Gulf of California, Mexico. Oecologia 134(4): 496-504

Stapp P, Polis GA (2003b) Influence of pulsed resources and marine subsidies on insular rodent populations. Oikos 102(1): 111-123

Tamarin RH, Malecha SR (1971) The population biology of Hawaiian rodents: demographic parameters. Ecology 52(3): 383-394

Weaver PL, Murphy PG (1990) Forest structure and productivity in Puerto Rico's Luquillo Mountains. Biotropica 22(1): 69-82

Zuur A, leno EN, Walker N, Saveliev AA, Smith GM (2009) Mixed effects models and extensions in ecology with R. Springer Science \& BusinessMedia

Zuur AF, Hilbe JM, leno EN (2013) A beginner's guide to GLM and GLMM with R: a Frequentist and Bayesian perspective for ecologists. Highland Statistics Limited 